\title{
PERBANDINGAN METODE SEASONAL ARIMA DAN EXTREME LEARNING MACHINE PADA PERAMALAN JUMLAH WISATAWAN MANCANEGARA KE BALI
}

\section{Comparison of Seasonal ARIMA and Extreme Learning Machine Methods in Forecasting on the Number of Foreign Tourist to Bali}

\author{
Bayu Galih Prianda ${ }^{1^{*}}$, Edy Widodo ${ }^{2}$ \\ 1,2 Program Studi Statistika, Fakultas MIPA, Universitas Islam Indonesia \\ Jl. Kaliurang KM 14,5, Sleman, Yogyakarta, 55584
}

Corresponding authore-mail: 1*bayugalihprianda@gmail.com

\begin{abstract}
Abstrak
Pulau dewata Bali merupakan salah satu kekayaan destinasi wisata yang sangat populer dan memiliki jumlah pengunjung wisatawan mancanegara tertinggi di Indonesia. Maka sangat perlu dilakukan pembelajaran lebih mendalam yang berhubungan dengan proyeksi atau peramalan kunjungan wisman ke Bali pada kurun waktu tertentu. Analisis peramalan yang digunakan adalah dengan membandingkan dua metode, yaitu metode Seasonal ARIMA (SARIMA) dan Extreme Learning Machine (ELM). Metode SARIMA merupakan metode statistika yang biasa digunakan dalam peramalan pada data runtun waktu yang mengandung musiman dan memiliki akurasi yang baik. Sedangkan metode ELM merupakan metode pembelajaran baru dari jaringan syaraf tiruan yang memiliki learning speed yang cepat dan juga akurasi yang baik. Hasil penelitian yang diperoleh menunjukkan bahwa metode Seasonal ARIMA adalah metode yang lebih baik digunakan untuk meramalkan jumlah wisman ke Bali pada kasus ini, karena memiliki nilai MAPE peramalan yang lebih kecil yaitu sebesar 4.97\%. Sedangkan metode ELM memiliki nilai MAPE peramalan sebesar $7.62 \%$.
\end{abstract}

Kata Kunci : Seasonal ARIMA, Extreme Learning Machine, Wisatawan Mancanegara, Peramalan, MAPE.

\begin{abstract}
Bali Island of the Gods is one of the wealth of very popular tourist destinations and has the highest number of foreign tourists in Indonesia. It is very necessary to do more in-depth learning related to the projections or forecasting of foreign tourist visits to Bali at a certain period of time. Forecasting analysis used is to compare two methods, namely the Seasonal ARIMA method (SARIMA) and Extreme Learning Machine (ELM). The SARIMA method is a statistical method commonly used in forecasting time series data that contains seasonality and has good accuracy. While the ELM method is a new learning method of artificial neural networks that has fast learning speed and good accuracy. The results obtained indicate that the Seasonal ARIMA method is a better method used to predict the number of tourists to Bali in this case, because it has a smaller forecasting MAPE value of 4.97\%. While the ELM method has a forecasting MAPE value of $7.62 \%$.
\end{abstract}

Keywords: Seasonal ARIMA, Extreme Learning Machine, International Tourists, Forecasting, MAPE

Article info:

Submitted: $30^{\text {th }}$ June $2021 \quad$ Accepted: $23^{\text {rd }}$ October 2021

How to cite this article:

B. G. Prianda, and E. Widodo, "PERBANDINGAN METODE SEASONAL ARIMA DAN EXTREME LEARNING MACHINE PADA PERAMALAN JUMLAH WISATAWAN MANCANEGRA KE BALI”, BAREKENG: J. Il. Mat. \& Ter., vol. 15, no. 04, pp. 639-650, Dec. 2021.

This work is licensed under a Creative Commons Attribution-ShareAlike 4.0 International License. Copyright @ 2021 Bayu Galih Prianda, Edy Widodo 


\section{PENDAHULUAN}

Indonesia merupakan negara yang memiliki potensi wisata yang sangat melimpah, memiliki berbagai keindahan alam, keanekaragaman budaya maupun sejarahnya. Banyak tempat-tempat wisata menarik di seluruh pulau maupun daerah di Indonesia yang dapat dikunjungi wisatawan. Pulau dewata Bali merupakan salah satu kekayaan destinasi wisata yang sangat populer dan memiliki jumlah pengunjung wisatawan mancanegara tertinggi di Indonesia. Mengingat potensi besar yang mampu dihasilkan oleh sektor pariwisata di Bali, maka sangat perlu dilakukan pembelajaran lebih mendalam yang berhubungan dengan proyeksi atau peramalan kunjungan wisman ke Bali pada kurun waktu tertentu. Hasil peramalan ini sangat penting untuk menyusun dan penetapan strategi di bidang pariwisata. Untuk memperoleh gambaran capaian wisman, maka diperlukan metode peramalan banyaknya jumlah wisatawan mancanegara yang berkunjung ke Bali.

Ada beberapa metode yang dapat digunakan dalam peramalan, antara lain metode Seasonal Autoregressive Integrated Moving Average (SARIMA) dan metode Extreme Learning Machine (ELM). Metode SARIMA merupakan metode statistika yang biasa digunakan dalam peramalan. SARIMA adalah pengembangan dari model ARIMA (Box Jenkins) pada data runtun waktu yang memiliki pola musiman [5]. Metode SARIMA pernah digunakan oleh Hutomo Atman Maulana, dkk untuk meramalkan jumlah produksi kopi Indonesia yang menggunkaan model $\operatorname{SARIMA}(2,1,0)(1,1,1)^{12}[10]$. Selain itu metode SARIMA juga pernah digunakan untuk meramalkan jumlah wisatawan mancanegara ke Pekanbaru oleh Munawaroh dan M.M. Nizam yang memiliki tingkat akurasi yang baik dengan menggunakan model SARIMA $(2,0,0)(0,0,1)^{12}$ [13]. Verawaty dkk membuat sebuah penelitian tentang peramalan inflasi di Indonesia dengan menggunakan model terbaik SARIMA $(1,0,0)(0,1,0)^{12}$ dan hasil peramalannya memiliki pola yang sama dengan pola pada waktu sebelumnya [15]. Kelebihan dari metode SARIMA adalah relatif mudah untuk digunakan dalam memprediksi data runtun waktu berpola musiman [1].

Selain metode statistika yang umum digunakan dalam peralaman, terdapat metode jaringan syaraf tiruan yang merupakan kecerdasan buatan komputer, dimana mampu menganalisa pola data kemudian memprediksikan peramalan. Salah satu metode jaringan syaraf tiruan adalah ELM. Metode ini merupakan pembelajaran baru dari Artificial Neural Network (ANN). ELM merupakan jaringan syaraf tiruan feedforward yang memiliki satu hidden layer atau sering disebut dengan Single Hidden Layer Feedforward (SLFNs) [9]. Metode ELM pernah digunakan oleh Pratama dkk, untuk meramalakan harga saham Bank Mandiri dan memperoleh nilai MAPE sebesar 1,01\% (sangat baik) dengan menggunakan fungsi aktivasi sigmoid [12]. Penelitian lain oleh Cusan Mosabeth dkk juga menggunakan metode ELM untuk meramalkan harga daging sapi di Kota Malang yang diperoleh nilai error atau MAPE sebesar 0,34\% dengan menggunakan perbandingan data training dan testing masing-masing 90\%:10\% [5]. Yasinta menggunakan metode ELM untuk meramalkan jumlah wisman Sulawesi Tenggara dengan hasil pengujian menggunakan 100 hidden layer [17]. Metode ELM digunakan oleh Delia dkk untuk meramlakan jumlah kunjungan pasien di Poli Gigi RSU dr. Wahidin Sudiro Husodo Mojokerjo, yang hasil penelitiannya berupa sistem pendukung keputusan untuk meramalakan jumlah kunjungan pasien [6].

Pada penelitian ini, penulis tertarik untuk menerapkan dua buah metode peramalan yang berbeda, yakni metode statistika klasik dengan menggunakan SARIMA dan metode jaringan syaraf tiruan menggunakan ELM, untuk mengetahui prediksi jumlah wisatawan mancanegara yang berkunjung ke Bali. Kemudian dari kedua metode yang digunakan, maka dibandingkan dan diketahui metode mana yang lebih baik untuk digunakan dalam meramalkan jumlah wisatawan mancanegara ke Bali.

\section{METODE PENELITIAN}

\subsection{Tahapan Penelitian}

Adapun beberapa tahapan penelitian yang dilakukan, yang pertama menentukan topik penelitian terlebih dahulu. Kemudian merumuskan masalah dan menentukan manfaat dari penelitian yang akan dilakukan. Selanjutnya peneliti mencari studi literatur atau referensi dari berbagai sumber seperti jurnal, buku dan sebagainya untuk mendukung kegiatan penelitian. Lalu peneliti mengumpulkan data yang akan diolah atau dianalisis yang kemudian akan diimplementasikan menggunakan metode SARIMA dan ELM. Setelah dilakukan analisis dengan penerapan kedua metode tersebut, kemudian peneliti membandingkan performa dari kedua metode untuk mengetahui metode mana yang lebih baik dalam melakukan peramalan pada kasus yang telah ditetapkan dengan melihat nilai error. Selanjutnya hasil analisis yang telah dilakukan kemudian 
diinterpretasikan dan ditarik kesimpulan serta saran. Tahapan penelitian divisualisasikan dalam bentuk flowchart yang dapat dilihat pada Gambar 1 di halaman berikutnya.

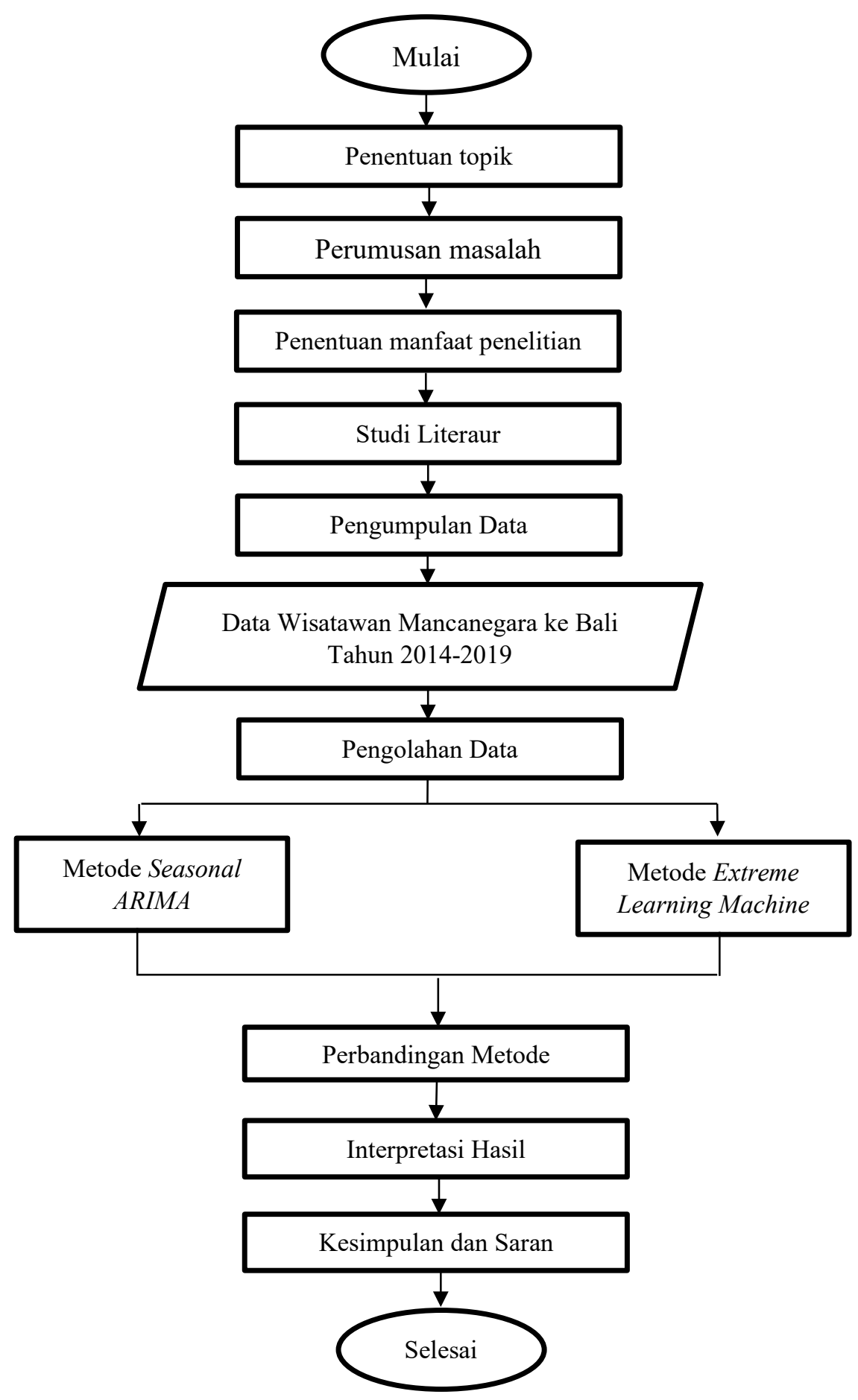

Gambar 1. Flowchart Penelitian

\subsection{Seasonal Autoregressive Integrated Moving Average (SARIMA)}

SARIMA merupakan pengembangan model ARIMA pada data runtun waktu yang memiliki pola musiman. Metode SARIMA ini dipopulerkan oleh George Box dan Gwilym Jenskins sekitar tahun 1970-an, model ini telah banyak dipelajari secara luas dan mengadopsi salah satu model yaitu ARIMA model. SARIMA juga merupakan metode analisis time series, sama seperti analisis tren, moving average atau naïve [8].

Deret berkala musiman yaitu deret berkala yang mempunyai sifat berulang setelah beberapa periode waktu tertentu, misalnya satu tahun, satu bulan, triwulan, dan sebagainya. Oleh karena itu, deret berkala 
musiman mempunyai karakteristik yang ditunjukkan adanya korelasi yang kuat. Persamaan model SARIMA atau ARIMA musiman $(\mathrm{p}, \mathrm{d}, \mathrm{q})(\mathrm{P}, \mathrm{D}, \mathrm{Q})^{\mathrm{s}}$ dengan rumus sebagai berikut [16]:

$$
\phi_{p}(B) \phi_{P}\left(B^{s}\right)(1-B)^{d}\left(1-B^{S}\right)^{D} X_{t}=\theta_{q}(B) \theta_{Q}\left(B^{s}\right) e_{t}
$$

\section{dengan}

$X_{t} \quad$ : nilai variabel $X$ pada periode ke- $t$

$e_{t} \quad$ : nilai error periode ke- $t$

$\theta_{Q} \quad$ : parameter MA musiman

$\phi_{p} \quad$ : parameter AR nonmusiman

$S \quad$ : jumlah periode musiman

$\phi_{P} \quad$ : parameter AR musiman

$d \quad$ : jumlah ordo differencing nonmusiman

$\theta_{q} \quad$ : parameter MA nonmusiman

D : jumlah ordo differencing musiman

Sebagai contoh, terdapat sebuah model ARIMA $(0,1,1)(0,1,1)^{12}$, maka dapat dituliskan persamaan modelnya sebagai berikut:

$$
(1-B)\left(1-B^{12}\right) X_{t}=\left(1-\theta_{1} B\right)\left(1-\theta_{1} B^{12}\right) e_{t}
$$

Namun agar dapat menggunakan suatu model yang ditetapkan untuk peramalan, perlu dilakukan pengembangan persamaan tersebut. Maka model dapat dikembangkan sebagai berikut:

$$
X_{t}=X_{t-1}+X_{t-12}-X_{t-13}-\theta_{1} e_{t-1}-\theta_{1} e_{t-12}+\theta_{1} e_{t-13}+e_{t}
$$

\subsection{Extreme Learning Machine (ELM)}

ELM merupakan metode pembelajaran baru dari Jaringan Syaraf Tiruan atau Artificial Neural Network (ANN) yang pertama kali dicetuskan oleh Huang, dkk [9]. ELM melambangkan bagian dari jaringan syaraf tiruan feedforward sederhana dengan Single Hidden Layer Feedforward neural Networks (SLFNs) [14].

Metode pembelajaran ELM dibuat untuk mengatasi kelemahan-kelemahan dari jaringan syaraf tiruan lainnya terutama dalam hal learning speed. Pada ELM parameter-parameter seperti input weight dan bias dipilih secara random, sehingga ELM memiliki learning speed yang cepat dan mampu menghasilkan good generalized performance [4]. Secara umum struktur jaringan ELM ditunjukkan pada Gambar 1 berikut:

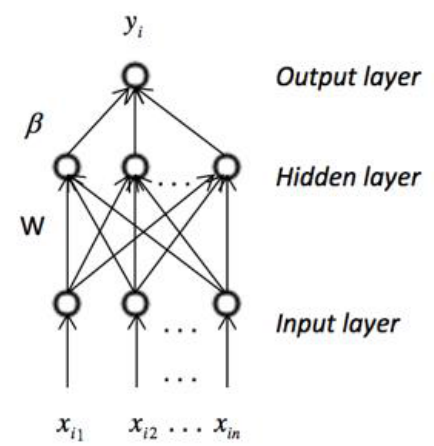

Gambar 2. Struktur Jaringan ELM

Sumber: [2]

dengan:

$w \quad$ : weight atau bobot yang menghubungkan input nodes dan hidden nodes

$\beta \quad$ : weight vector yang menghubungkan hidden nodes dan output nodes

$y_{i} \quad$ : nilai output

\subsection{Uji Validitas}

Uji validitas untuk mengevaluasi terhadap ketepatan hasil peramalan dengan melihat ukuran kesalahan peramalan. Salah satu cara untuk mengukur ketepatan model peramalan, yaitu dengan menggunakan nilai MAPE (Mean Absolute Percentage Error). MAPE adalah metode yang mengukur ketepatan nilai dugaan model yang dinyatakan dalam bentuk rata-rata persentase absolut kesalahan [18]. 
Metode ini melakukan perhitungan perbedaan antara data asli dan data hasil peramalan perbedaan tersebut diabsolutkan, kemudian dihitung ke dalam bentuk persentase terhadap data asli. Hasil persentase tersebut kemudian diperloeh rata-ratanya [7]. Suatu model mempunyai kinerja sangat bagus jika nilai MAPE berada di bawah $10 \%$, sedangkan jika nilai MAPE berada pada rentang $10 \%$ sampai $20 \%$ mempunyai kinerja bagus. Berikut adalah rumus persamaan dalam mencari nilai MAPE [11]:

$$
M A P E=\frac{100 \%}{n} \sum_{t=1}^{n}\left|\frac{X_{t}-X_{t}^{\prime}}{X_{t}}\right|
$$

dengan:

$X_{t} \quad$ : data aktual pada periode ke- $t$

$X_{t}{ }_{t} \quad$ : data peramalan pada periode ke- $t$

$n \quad$ : jumlah data yang digunakan

\section{HASIL DAN PEMBAHASAN}

\subsection{Analisis Deskriptif}

Berdasarkan data Kementerian Pariwisata Indonesia, pertumbuhan wisman yang berkunjung ke Bali berdasarkan pintu masuk bandara internasional Ngurah Rai seperti pada Gambar 2, selalu mengalami peningkatan setiap tahunnya. Dalam enam tahun terakhir ini jumlah wisatawan mancanegara tidak pernah mengalami penurunan, bahkan pergerakan menunjukkan peningkatan yang cukup pesat. Tercatat dari 3.640.173 wisman pada tahun 2014 menjadi 6.239.543 wisman pada tahun 2019 yang berkunjung ke Bali melalui pintu masuk bandara Ngurah Rai. Jumlah wisman tertinggi terjadi pada tahun 2019 yaitu sebesar 6.239.543 wisman. Sedangkan jumlah wisatawan mancanegara yang berkunjung ke Bali paling rendah terjadi pada tahun 2014 dengan jumlah wisman sebesar 3.640.173. Peningkatan terbesar terjadi pada tahun 2015 ke tahun 2016, dimana jumlah wisatawan mancanegara naik sebesar 23,6\% atau meningkat sebesar 932.508 wisman dari tahun sebelumnya.

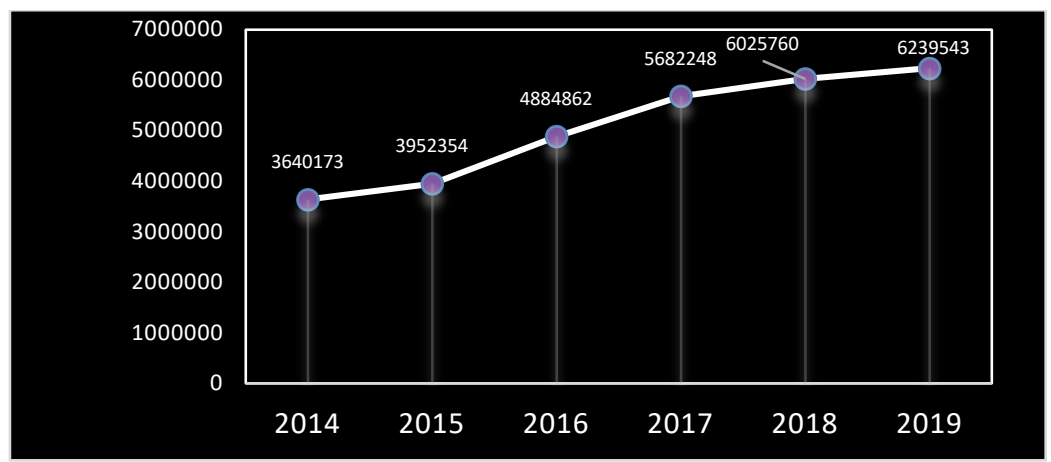

Gambar 3. Grafik Jumlah Wisman ke Bali melalui pintu masuk bandara Ngurah Rai Tahun 2014-2019

Sumber: Kementerian Pariwisata Indonesia

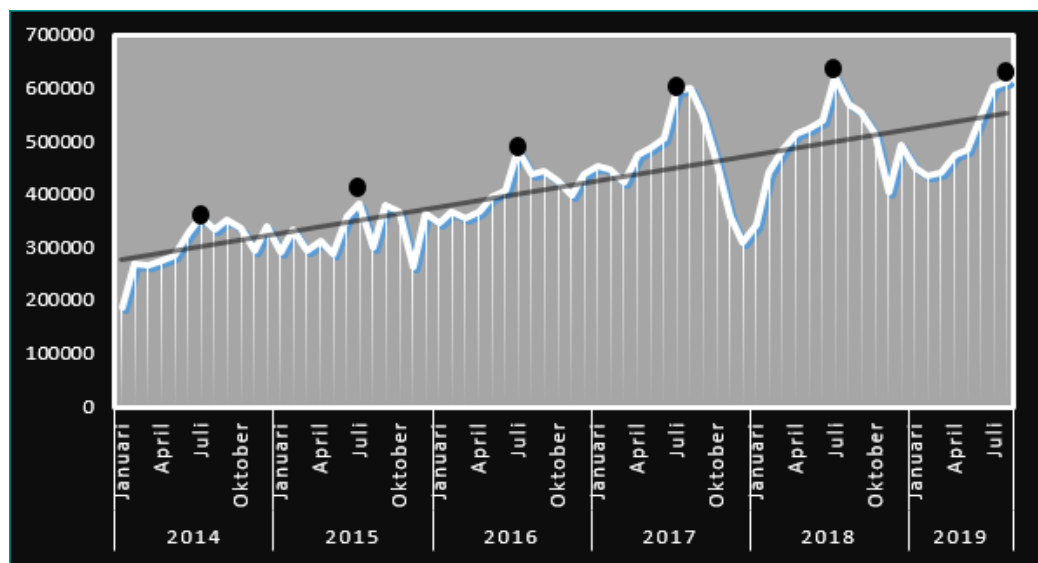

Gambar 4. Pola Data Time Series Jumlah Wisman ke Bali melalui pintu masuk bandara Ngurah Tahun 2014-2019

Sumber: Kementerian Pariwisata Indonesia 
Sebagaimana ditunjukkan pada Gambar 3. bahwa pola data mengalami kecenderungan naik dan mengandung pola musiman. Pola musiman pada data ditunjukkan oleh naik turunnya data yang berulang dalam setiap tahunnya. Dapat dilihat bahwa pada setiap pertengahan tahun yaitu sekitar bulan Juli, grafik selalu menunjukkan titik puncak peningkatan. Lonjakan jumlah wisman yang terjadi pada bulan tersebut disebabkan oleh wisatawan asal Tiongkok dan Australia yang berkunjung ke Bali. Dimana pada bulan Juli merupakan musim libur sekolah di Australia dan libur musim panas yang sekaligus libur sekolah di Tiongkok. Hal inilah yang menyebabkan terjadinya lonjakan jumlah wisman pada bulan tersebut, yang mana jumlah wisman yang berkunjung di Bali didominasi oleh wisman asal Tiongkok dan Australia.

\subsection{Seasonal ARIMA}

\section{a. Uji Normalitas}

Uji normalitas digunakan untuk mengetahui kenormalan suatu data, dimana kenormalan suatu data juga dapat mengindikasikan bahwa data tersebut stasioner dalam varians. Berikut adalah hipotesis dari uji normalitas.

$\mathrm{H}_{0}$ : data berdistribusi normal

$\mathrm{H}_{1}$ : data tidak berdistribusi normal

Nilai $p$-value yang diperoleh dari uji normalitas adalah $0.3956>\alpha(0.05)$, maka keputusan gagal tolak $\mathrm{H}_{0}$. Dengan menggunakan tingkat kepercayaan 95\% dapat disimpulkan bahwa data berdistribusi normal.

\section{b. Stasioneritas dalam Mean}

Data dikatakan stasioner dalam mean apabila fluktuasi data berada di sekitar suatu nilai rata-rata yang konstan. Dalam melakukan pemeriksaan stasioneritas terhadap rata-rata, dapat diidentifikasi melalui plot datanya atau plot ACF (Autocorrelation Function). Visualisasi plot ACF dapat dilihat pada Gambar 5 di halaman berikutnya.

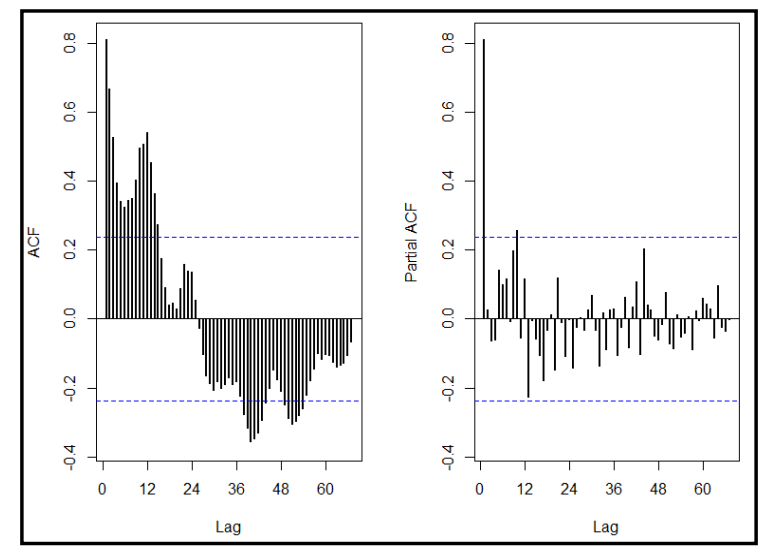

Gambar 5. Plot ACF dan PACF

Terlihat pada Gambar 5. bahwa plot fungsi ACF dari data mengalami penurunan atau meluruh secara perlahan. Hal ini menandakan adanya sifat nonstasioner dalam rata-rata, maka perlu dilakukan differencing.

\section{c. Differencing}

Differencing merupakan suatu bentuk transformasi untuk menstasionerkan data runtun waktu yang tidak stasioner dalam mean. Dikarenakan pola data mengandung komponen musiman dan tren, maka perlu dilakukan proses diferensiasi musiman dan musiman. Setelah dilakukan proses differencing musiman maupun nonmusiman dengan tujuan untuk menstasionerkan data dalam mean, maka selanjutnya dilakukan pemeriksaan kembali kestasioneran data dalam mean dengan melihat plot data time series maupun plot ACF. 


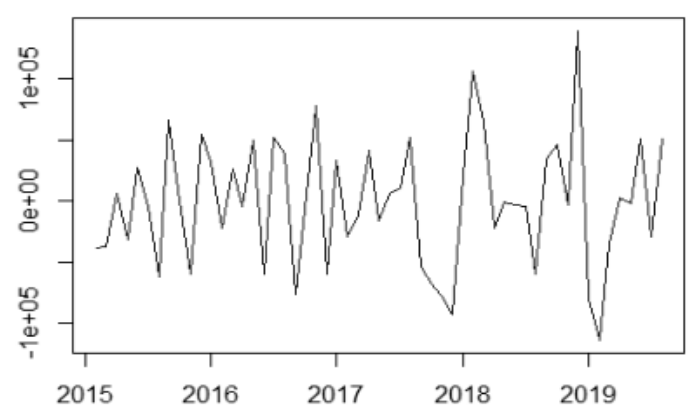

Gambar 6. Plot Data setelah Differencing
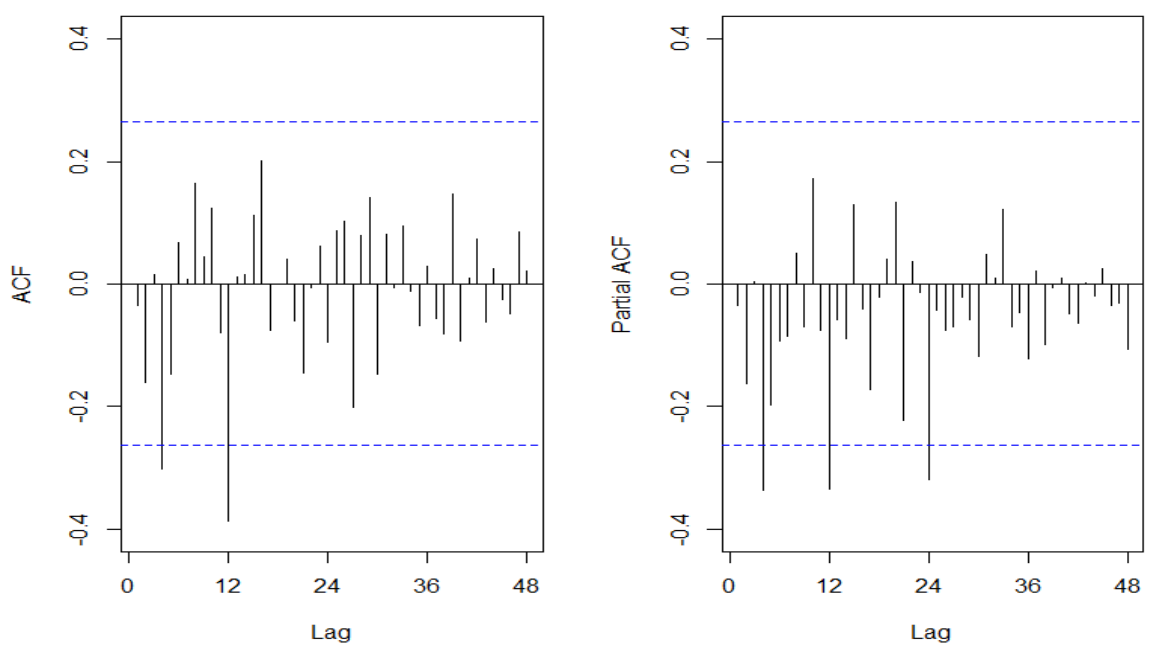

Gambar 7. Plot ACF dan PACF setelah Differencing

Sebagaimana pada Gambar 6. yang merupakan plot data time series jumlah wisman yang berkunjung ke Bali melalui pintu masuk bandara Ngurah Rai dari bulan Januari 2014 sampai Agustus 2019, setelah dilakukan differencing plot tampak membentuk pola horizontal yang bergerak di sekitaran rata-rata yang konstan, sehingga dapat diindikasikan bahwa data telah stasioner dalam mean.

Plot ACF yang ditunjukkan pada Gambar 7. terlihat tidak adanya penurunan secara perlahan, dapat dikatakan bahwa komponen trend dalam data sudah tidak ada. Sehingga dalam hal ini dapat diperoleh bahwa data telah stasioner dalam mean.

\section{d. Identifikasi Model}

Identifikasi model dilakukan setelah dipastikan bahwa data telah stasioner. Model SARIMA biasanya dinotasikan SARIMA $(\mathrm{p}, \mathrm{d}, \mathrm{q})(\mathrm{P}, \mathrm{D}, \mathrm{Q})^{\mathrm{S}}$. Dalam hal ini $\mathrm{p}$ dan $\mathrm{q}$ adalah urutan masing-masing AR dan MA, dimana $\mathrm{d}$ adalah urutan pembeda. Model dapat ditentukan dimana biasanya dengan $p=1-5$ lag, dan $\mathrm{q}=1-3$ lag [3]. Berdasarkan plot ACF dan PACF seperti pada Gambar 7. dapat dilakukan identifikasi model awal. Untuk model nonmusiman dilihat dari plot PACF terdapat lag yang keluar garis batas yaitu lag ke-4 sehingga nilai $\mathrm{p}=4$, dan plot ACF dari 3 lag awal tidak ada yang melewati garis batas, sehingga nilai $\mathrm{q}=0$. Differencing nonmusiman dilakukan sebanyak 1 kali, maka $\mathrm{d}=1$. Sedangkan untuk model musiman, pada plot PACF terdapat lag ke-12 dan lag ke-24 yang keluar melewati batas, maka nilai $\mathrm{P}=2$. Pada plot ACF lag ke-12 melewati garis batas, sehingga nilai $\mathrm{Q}=1$. Differencing musiman dilakukan sebanyak 1 kali, maka nilai $\mathrm{D}=1$. Dengan demikian model awal yang terbentuk yaitu SARIMA $(4,1,0)(2,1,1)^{12}$.

Apabila model awal telah diperoleh, kemudian dilakukan pengembangan model atau dimodifikasi menjadi beberapa model dan dilakukan estimasi model parameter. Maka diperoleh model yang parameternya signifikan dan memiliki nilai AIC terkecil yaitu model SARIMA $(0,1,0)(2,1,0)^{12}$.

\section{e. Uji Diagnostik}

Uji diagnostik digunakan untuk melihat apakah residual dari model bersifat white noise atau tidak. White noise menunjukkan bahwa suatu data bersifat random dan stasioner, dimana ini merupakan syarat untuk melakukan peramalan. Pengecekan diagnostik dapat dilakukan dengan menggunakan Ljung-Box Test. Nilai $p$-value yang diperoleh dari uji diagnostic adalah $0.3713>\alpha(0.05)$, maka keputusan gagal tolak $\mathrm{H}_{0}$. Sehingga dengan menggunakan tingkat kepercayaan 95\% dapat disimpulkan bahwa tidak terdapat 
autokorelasi antar residual. Berdasarkan hasil uji diagnostik yang telah dilakukan, dapat dikatakan bahwa asumsi white noise terpenuhi pada model terbaik, yaitu model SARIMA $(0,1,0)(2,1,0)^{12}$, sehingga model tersebut layak digunakan untuk peramalan.

\section{f. Hasil Peramalan Metode SARIMA}

Berikut adalah hasil peramalan untuk 4 periode setelahnya, yaitu periode 69 , periode 70 , periode 71 dan periode 72 dengan menggunakan persamaan model SARIMA $(0,1,0)(2,1,0)^{12}$.

\begin{tabular}{cc} 
Tabel 1. Hasil Peramalan Jumlah Wisman \\
\hline Periode ke & Hasil Peramalan \\
\hline 69 (Sep-2019) & 585361 \\
70 (Okt-2019) & 540537 \\
71 (Nov-2019) & 463038 \\
72 (Des-2019) & 498155 \\
\hline
\end{tabular}

\subsection{Extreme Learning Machine}

\section{a. Normalisasi Data}

Pada proses peramalan menggunakan metode ELM, hal pertama yang harus dilakukan adalah normalisasi data. Normalisasi data ini bertujuan untuk mengubah range data menjadi lebih kecil, agar data dapat dilatih dengan metode ELM. Metode ELM merupakan metode pelatihan, sehingga jika semakin banyak data training yang digunakan maka akan semakin baik prediksi yang akan dihasilkan dengan melihat nilai error yang kecil [2]. Dalam penelitian ini range data yang digunakan untuk normalisasi data yaitu -0.8 hingga 0.8. Berikut adalah hasil normalisasi data yang telah dilakukan dengan menggunakan metode Min-Max Normalization sebagaimana pada Tabel 2.

Tabel 2. Hasil Normalisasi Data

\begin{tabular}{ccrr}
\hline Tahun & Bulan & $\begin{array}{c}\text { Jumlah } \\
\text { Wisman }\end{array}$ & Normalisasi \\
\hline 2014 & Januari & 187123 & -0.8 \\
& Februari & 269367 & -0.499 \\
$:$ & $:$ & & $:$ \\
2019 & Agustus & 615027 & $:$ \\
\hline
\end{tabular}

\section{b. Proses Training}

Proses pelatihan atau training dilakukan sebelum melakukan peramalan. Adapun arsitektur jaringan yang digunakan dalam proses training untuk meramalkan jumlah wisatawan mancanegara ke Bali, yaitu menggunakan 12 input layer, 54 hidden layer dan 1 output layer. Data yang telah dinormalisasi dimasukkan sebagai data input sebanyak 12 input layer, yaitu X1, X2, X3, sampai X12. Berikut adalah pola input data training yang telah dinormalisasi kemudian dibentuk seperti Tabel 3.

Tabel 3. Data Proses Training

\begin{tabular}{ccccccc}
\hline Data & Target & \multicolumn{5}{c}{ Node Input } \\
\hline $\mathbf{i}$ & $\boldsymbol{t}_{\boldsymbol{i}}$ & $\mathbf{X 1}$ & $\mathbf{X 2}$ &.. & $\mathbf{X 1 1}$ & $\mathbf{X 1 2}$ \\
\hline 1 & -0.42011 & -0.23638 & -0.40933 &.. & -0.49897 & -0.8 \\
2 & -0.26096 & -0.42011 & -0.23638 &.. & -0.50245 & -0.49897 \\
$:$ & $:$ & $:$ & $:$ &.. & $:$ & $:$ \\
$:$ & $:$ & $:$ & $:$ &.. & $:$ & $:$ \\
55 & 0.726969 & 0.526294 & 0.286352 &.. & 0.60644 & 0.8 \\
56 & 0.720187 & 0.726969 & 0.526294 &.. & 0.54973 & 0.60644 \\
\hline
\end{tabular}

Tabel 3 merupakan data yang digunakan dalam proses training. Nilai X1, X2, sampai X12 merupakan banyaknya node pada input layer. Sedangkan $t_{i}$ merupakan target yang digunakan untuk perhitungan menghasilkan keluaran hidden layer pada proses training. Nilai target dimulai dari data ke 13 dikarenakan jumlah node input sebanyak 12. Sebagai contoh, pola data pertama terdiri dari input X12 yang merupakan data ke-1 yang telah dinormalisasi (sebagaimana pada Tabel 3) yaitu -0.8, nilai input X11 merupakan data ke-2 yaitu -0.49897 dan seterusnya hingga nilai input X1 yang merupakan data ke-12 yaitu -0.23638 , lalu targetnya adalah data ke-13 (-0.42011). Begitu pula dengan pola data selanjutnya, dimana pada pola data 
kedua dengan nilai input X12 yang dimulai dari data ke-2 hingga input X1 adalah data ke-13 dengan target data ke-14, dan seterusnya hingga pola data ke-54.

Adapun hasil arsitektur jaringan ini diperoleh dengan menggunakan bantuan software R. Berikut adalah gambar arsitektur jaringan ELM yang digunakan dapat dilihat pada Gambar 8. Banyaknya node pada input layer, yaitu 12 node yang mewakili jumlah bulan pada data input yang ada. Di dalam proses training terdapat nilai bobot input yang diinisialisasi secara random untuk menghitung keluaran pada hidden layer. Dengan jumlah node input sebanyak 12 dan jumlah hidden layer sebanyak 54, maka bobot inputnya ada sebanyak 648. Setiap node input memiliki 54 bobot yang menyebar ke masing-masing node pada hidden layer.

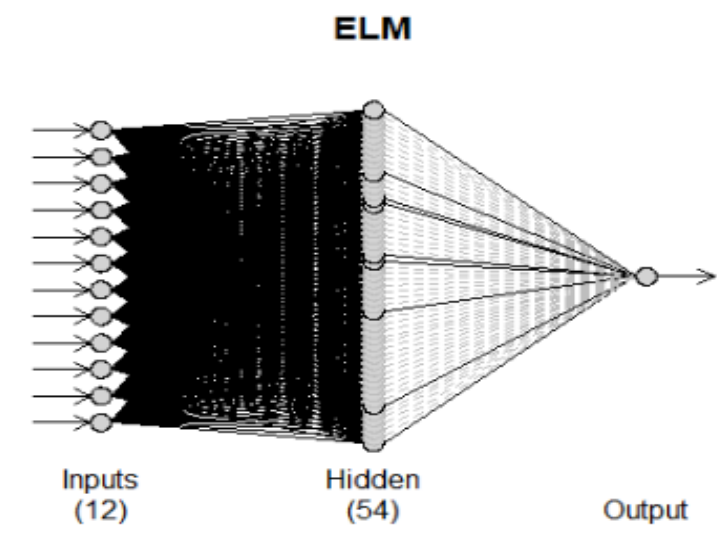

Gambar 8. Arsitektur Jaringan ELM

Diketahui bahwa pada node input X1 terdapat 54 bobot, yaitu $W_{1.1}, W_{1.2}, W_{1.3}$, sampai $W_{1.54}$, begitu seterusnya pada node-node input lainnya. Kemudian pada hidden layer terjadi perhitungan dengan menggunakan fungsi aktivasi untuk menghasilkan keluaran hidden layer, yang selanjutnya diperoleh bobot antara hidden layer dan output layer. Setelah memperoleh bobot antara hidden layer dan output layer maka dilakukan perhitungan pada output layer untuk hasil prediksinya. Berikut adalah output dari proses training yang berupa hasil prediksi, dapat dilihat pada Tabel 4.

Tabel 4. Hasil Prediksi

\begin{tabular}{cccc}
\multicolumn{4}{c}{ Tabel 4. Hasil Prediksi } \\
\multirow{2}{*}{ Tahun } & \multirow{2}{*}{ Bulan } & $\begin{array}{c}\text { Jumlah } \\
\text { Wisman }\end{array}$ & Prediksi \\
\hline \multirow{2}{*}{2015} & Januari & 290914 & 325190 \\
& Februari & 334396 & 332609 \\
$:$ & $:$ & $:$ & $:$ \\
2019 & Agustus & 615027 & 557907 \\
\hline
\end{tabular}

\section{c. Hasil Peramalan Metode ELM}

Setelah proses training dilakukan dan mendapatkan hasil prediksi, selanjutnya adalah dilakukan peramalan menggunakan metode ELM. Berikut adalah hasil peramalan 4 periode yang telah dilakukan menggunakan metode ELM dengan menggunakan 12 input layer dan 54 hidden layer.

Tabel 5. Hasil Peramalan ELM

\begin{tabular}{cc}
\hline Periode ke & Hasil Peramalan \\
\hline 69 (Sep-19) & 541388 \\
$70($ Okt-19) & 523391 \\
$71($ Nov-19) & 481685 \\
$72($ Des-19) & 476744 \\
\hline
\end{tabular}

Tabel 5 merupakan hasil peramalan tiga periode dengan metode ELM. Hasil peramalan jumlah wisman yang berkunjung ke Bali untuk periode September 2019 yaitu 541388. Sedangkan untuk periode Oktober, November dan Desember 2019 masing-masing hasil peramalannya, yaitu sebesar 523391, 481685 dan 476744. Berikut adalah grafik antara data aktual dan peramalan dapat dilihat pada Gambar 9. 


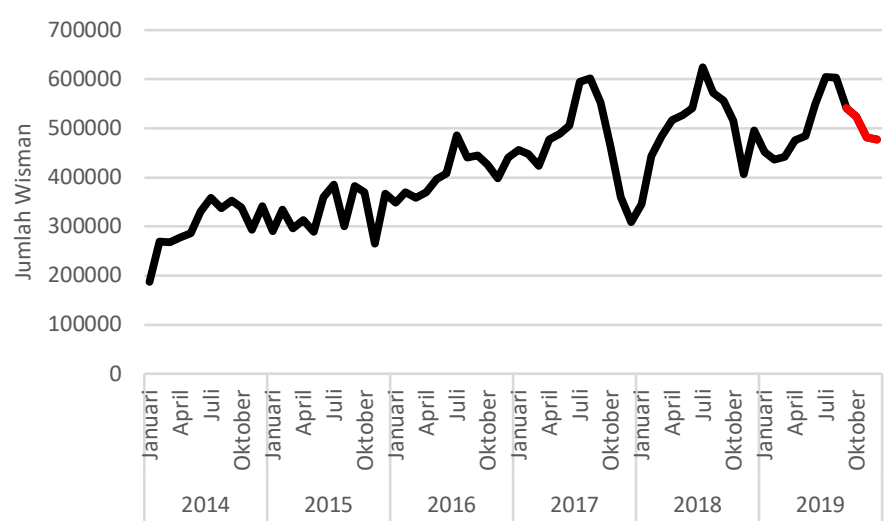

Gambar 9. Grafik Data Aktual vs Peramalan

Hasil peramalan digambarkan dengan garis yang berwarna merah sebagaimana pada Gambar 9, sedangkan data aslinya yang berwarna biru. Dapat dilihat bahwa garis peramalan yang berwarna merah menunjukkan bahwa pola tersebut mirip dengan pola pada musim-musim sebelumnya yang mengalami penurunan pada periode tersebut.

\subsection{Uji Validitas dan Perbandingan Metode}

Pada tahap ini dilakukan uji ketepatan model atau uji validitas hasil peramalan dengan menggunakan nilai MAPE (Mean Absolute Percentae Error) dari masing-masing metode. Dalam sebuah tesis oleh Lohy [18] dikatakan bahwa MAPE adalah metode untuk mengukur ketepatan nilai dugaan model, yang dinyatakan dalam bentuk rata-rata persentase absolut kesalahan. Berdasarkan nilai MAPE dari masing-masing metode, kemudian akan dapat diketahui metode manakah lebih baik dalam meramalkan jumlah wisatawan mancanegara ke Bali. Berikut hasil perhitungan nilai MAPE dari hasil peramalan yang dapat dilihat pada Tabel 6 dan 7 pada halaman berikutnya.

Tabel 6. Nilai MAPE Metode SARIMA

\begin{tabular}{lrrr}
\hline Periode ke & $\begin{array}{c}\text { Data Asli } \\
\text { (Testing) }\end{array}$ & $\begin{array}{c}\text { Hasil } \\
\text { Peramalan }\end{array}$ & MAPE \\
\hline $\begin{array}{l}\text { 69 (Sep- } \\
\text { 2019) }\end{array}$ & 589984 & 585261 & \\
$\begin{array}{l}70(\text { Okt- } \\
2019)\end{array}$ & 565966 & 540537 & \\
$71($ Nov- & 492904 & 463038 & \\
$\begin{array}{l}\text { 2019) } \\
72(\text { Des- }\end{array}$ & 544726 & 498155 & \\
$2019)$ & & & \\
\hline
\end{tabular}

Tabel 7. Nilai MAPE Metode ELM

\begin{tabular}{lrrr}
\hline Periode ke & $\begin{array}{c}\text { Data Asli } \\
\text { (Testing) }\end{array}$ & $\begin{array}{c}\text { Hasil } \\
\text { Peramalan }\end{array}$ & MAPE \\
\hline $\begin{array}{l}\text { 69 (Sep- } \\
2019)\end{array}$ & 589984 & 541388 & \\
$70($ Okt- & 565966 & 523391 & \\
$\begin{array}{l}2019) \\
71(\text { Nov- }\end{array}$ & 492904 & 481685 & \\
$\begin{array}{l}\text { 2019) } \\
72(\text { Des- }\end{array}$ & 544726 & 476744 & \\
$2019)$ & & & \\
\hline
\end{tabular}

Berdasarkan hasil perhitungan nilai MAPE pada dari kedua metode sebagaimana pada Tabel 6 dan Tabel 7, diperoleh nilai MAPE peramalan jumlah wisman yang berkunjung ke Bali menggunakan metode SARIMA yaitu sebesar 4.97\%. Sedangkan untuk metode ELM diperoleh nilai MAPE peramalan sebesar 7.62\%. Dalam sebuah jurnal penelitian Yasa, dkk [11] menyatakan bahwa semakin kecil jumlah kuadrat kesalahan, maka model yang digunakan akan semakin baik untuk dilakukan peramalan. Suatu model mempunyai kinerja sangat bagus apabila nilai MAPE berada dibawah 10\%, dan mempunyai kinerja bagus apabila nilai MAPE berada pada rentang 10\% hingga 20\%. Sehingga dapat dikatakan bahwa hasil peramalan dari kedua metode tersebut sangat bagus karena memiliki nilai MAPE di bawah $10 \%$.

Diperoleh nilai MAPE dari metode SARIMA yaitu 4.97\% yang lebih kecil dibandingkan dengan nilai MAPE metode ELM, yakni 7.62\%. Sehingga dapat dikatakan bahwa metode SARIMA yang lebih baik digunakan untuk peramalan pada studi kasus ini. 


\section{KESIMPULAN}

Berdasarkan hasil penelitian yang telah dilakukan, maka dapat disimpulkan sebagai berikut:

1. Perbandingan metode SARIMA dan ELM berdasarkan hasil peramalan selama 4 periode, diperoleh bahwa kedua metode masing-masing memiliki nilai kesalahan atau MAPE peramalan di bawah $10 \%$ yang artinya kedua metode tersebut sangat baik dalam meramalkan selama 4 periode. Namun metode SARIMA masih lebih baik dibandingkan dengan metode ELM, karena metode SARIMA memiliki nilai MAPE sebesar $4.97 \%$ yang lebih kecil dibandingkan dengan metode ELM yang memiliki nilai MAPE sebesar $7.62 \%$.

2. Hasil peramalan yang dihasilkan oleh metode terbaik yaitu metode SARIMA, diprediksi mengalami peningkatan dari tahun sebelumnya. Diketahui hasil peramalan jumlah wisman ke Bali melalui pintu masuk bandara Ngurah Rai pada bulan September 2019 yaitu sebesar 585361 wisman atau diprediksi meningkat 5.3\% dari tahun sebelumnya. Jumlah wisman pada bulan Oktober diprediksi mencapai 540537 wisman atau naik sebesar $4.9 \%$ dari tahun sebelumnya. Prediksi jumlah wisman ke Bali bulan November 2019 yaitu sebesar 463038 wisman. Sedangkan pada bulan Desember 2019 diprediksi mencapai 498155 wisman dengan kenaikan $0.5 \%$ dari tahun sebelumnya.

\section{DAFTAR PUSTAKA}

[1] A. Assidiq, P. Hendikawati, and N. Dwidayanti, "Perbandingan Weighted Fuzzy Time Series, Seasonal ARIMA, dan HoltWinter's Exponential Smoothing untuk Meramalkan Data Musiman," UNNES Journal of Mathematics, Vol. 6, No. 2:129$142,2017$.

[2] A. Giusti, A.W. Widodo, and S. Adinugroho, "Prediksi Penjualan Mi Menggunakan Metode Extreme Learning Machine (ELM)," Jurnal Pengembangan Teknologi dan Ilmu Komputer, Vol. 2, No. 8: 2972-2978, Agustus 2018.

[3] A.K. Mishra, and V.R. Desai, "Drought forecasting using stochastic models," Stoch. Environ. Res. Risk Assess, 19:326339, Juni 2005.

[4] B.K. Khotimah, E.M. Sari, and H. Yulianarta, "Kinerja Metode Extreme Learning Machine (ELM) pada Sistem Peramalan," Jurnal SimanteC, Vol. 1, No. 3: 186-191, Desember 2010.

[5] C. Mosabeth, M.T. Furqon, and R.C. Wihandika, "Prediksi Harga Pasar Daging di Kota Malang dengan menggunakan Metode Extreme Learning Machine," Jurnal Pengembangan Teknologi Informasi dan Ilmu Komputer, Vol. 2, No. 12 : 6362 6369, Desember 2018.

[6] D.P. Fardani, E. Wuryanto, and I. Werdiningsih, "Sistem Pendukung Keputusan Peramalan Jumlah Kunjungan Pasien Menggunakan Metode Extreme Learning Machine," Journal of Information Systems Engineering and Business Intelligence, Vol. 1, No. 1: 33-40, April 2015.

[7] E. Fani, A.W. Widjajati, and Soehardjoepri, "Perbandingan Metode Exponential Smoothing dan Metode Event Based untuk Menentukan Penjualan Produk Terbaik di Perusahaan X," Jurnal Sains dan Seni ITS, Vol. 6, No. 1: A1-A5, 2017.

[8] F. I. Durrah, Yulia, T.P. Parhusip, and A. Rusyana,"Permalan Jumlah Penumpang di Bandara Sultan Iskandar Muda dengan Metode SARIMA," Journal of data Analysis, Vol. 1, No. 1: 1-11, Juni 2018.

[9] G.B. Huang, Q.Y. Zhu, and C.K. Siew, "Extreme Learning Machine Theory and Applications,” Neurocomputing, 489-501, Mei 2006.

[10] H.A. Maulana, K.W. Harahap, Adriyansyah, Rofiroh, and F. Zainuddin, "Pemodelan Produksi Kopi Indonesia dengan Menggunakan Seasonal Autoregressive Integrated Moving Average (SARIMA)," Jurnal SAINTIKA UNPAM, Vol. 2, No. 1: 1-14, Juli 2019.

[11] I.N.S. Yasa, I.K.G.D. Putra, and N.M.A.E.D. Wirastuti, "Peramalan Kurs Rupiah terhadap US Dollar menggunakan Metode Hibrid," Jurnal Teknologi Elektro, Vol. 16, No. 3: 33-38, Desember 2017.

[12] M.I. Pratama, P.P. Adikara, and S. Adinugroho, "Peramalan Harga Saham Menggunakan Metode Extreme Learning Machine (ELM)," Jurnal Pengembangan Teknologi Informasi dan Ilmu Komputer, Vol. 2, No. 11: 5009-4014, November 2018.

[13] R. Munawaroh, and M.M. Nizam, "Peramalan Wisatawan Mancanegara Ke Provinsi Riau melalui Kota Pekanbaru Menggunakan Metode SARIMA,” Jurnal Sains Matematika dan Statistika, Vol. 2, No. 2: 48-55, Juli 2016.

[14] S.N. Dewi, I.Cholissodin, and E. Santoso, "Prediksi Jumlah Kriminalitas Menggunakan Metode Extreme Learning Machine, ” Jurnal Pengembangan Teknologi Informasi dan Ilmu Komputer, Vol. 2, No. 11:4687-4693, Mei 2018.

[15] V.B. Sitorus, S. Wahyuningsih, and M.N. Hayati, "Peramalan dengan Metode SARIMA di Bidang Ekonomi," Jurnal EKSPONENSIAL, Vol. 8, No. 1: 17-25, Mei 2017.

[16] W.W.S. Wei, Time Series Analysis Univariate and Multivariate Method 2nd ed, New York (US): Pearson Education, 2006.

[17] Y.A. Sanudin, and J. Nugraha, "Penerapan Metode Extreme Learning Machine untuk Meramalkan Jumlah Wisatawan Mancanegara di Sulawesi Utara," Jurnal Sendika, Vol. 5, No. 2: 99-109, 2019.

[18] Y. Lohy, "Peramalan Penerimaan Pajak Hotel dengan Metode Runtun Waktu-ARIMA," Tesis. Institut Teknologi Sepuluh Nopember, 2017. 
